\title{
The Racism that Dares not Speak its Name: Rethinking Neo-nationalism and Neo-racism
} DDI: ID.17356/ieejsp.vlil.26

* [sindre.bangstad@teologi.uio.no] (Faculty of Theology, University of Oslo, Norway)

\begin{abstract}
In contemporary Norway, the mere referral to the term racism has for all practical purposes become a taboo in the public sphere. This is both the result of a strategic far-right distancing from classical forms of racism and a conscious effort by numerous Norwegian academics and public intellectuals to restrict its meaning and reference in the course of recent decades. Norway has a comparatively weak tradition of social science scholarship on racism, and persistent claims to the right to name racism on the part of minorities in Norway often come up against social and political imaginaries in which Norway and Norwegians are cast as 'exceptional' and 'virtuous.' In this article I contextualize Norwegian neo-racism with reference to persistent fears about lack of social and national cohesion arising from modern mass immigration and an increasingly multicultural Norwegian society. Using the methodology of critical discourse analysis, I take as my empirical starting point media and popular discourses on Islam and Muslims in Norway from 1987 to 2014. The rise of far-right political formations in Norway, I argue, must be understood not primarily through economic determinants, but seen as a result of a successful 'culturalization of politics' characteristic of neo-liberalism more generally.
\end{abstract}

Keywords: racism, neo-nationalism, neo-racism, islamophobia, muslims, Norway, far-right, populist rightwing, Progress Party. 


\section{Introduction}

In July 2004, the long-standing chairman and unrivalled leader of the Norwegian populist right-wing party the Progress Party or Fremskrittspartiet between 1977 and 2006, Mr Carl I. Hagen (1945-) delivered a speech to a Christian-evangelical congregation Levende Ord [The Living Word] in the city of Bergen on the Norwegian West Coast. At the backdrop of al-Qaida's terror attacks on the USA on September 112001 and the ensuing 'war on terror' which had by then led to the participation of Norwegian military troops in the NATO-led international military intervention (ISAF) in Afghanistan from 2002 onwards, and the US invasion and occupation of Iraq in 2003, Hagen declared to the enthusiastic crowd of thousands of Norwegian evangelical Christians gathered in the enormous assembly hall that "small Muslim children are used as suicide bombers [by Muslims] in order to Islamize the world." "We Christians", Hagen asserted, "are very concerned with children”. "Let the small children come unto me, said Jesus. I cannot understand that [the Prophet] Muhammad could have said the same. In case he had said anything reminiscent, it would have been 'let the small children come to me, so that I can exploit them in my struggle to Islamize the world"” (Alstadsæter 2004). Hagen notched the rhetoric up even further by asserting that "Muslims have, like Adolf Hitler, made it clear a long time ago that their long-term aim is to Islamize the world" (Tjønn et. al. 2004).

Yet in a newspaper interview in 2007, the doyen of Norwegian social anthropologists, Professor Fredrik W. Barth, declared in categorical terms that "when Norwegians talk about racism, they mean to refer to prejudices and stereotypes ... racist views are hardly found among Norwegians" (as cited in Gjerdåker 2007). And in the aftermath of the worst terrorist attacks in Norwegian history perpetrated by the racist extreme-right wing and intensely Islamophobic Norwegian Anders Behring Breivik, a Norwegian Professor of the History of Ideas, Professor Trond Berg Eriksen, declared in a newspaper interview that "harassment of Muslims in Norway is not racism" and that "anti-racists are the only ones who maintain the concept of race" (Simenstad 2011).

Modern academic scholarship on racism seems to make it reasonably clear that racism in its various articulations is a more or less universal phenomenon - and that there are no known societies in the world where racism has been rendered nonexistent (Back and Solomos 2000, Bethencourt 2013, Bulmer and Solomos 1999, Fredrickson 2002). So how then, does one account for the rather extraordinary claim from two senior and distinguished Norwegian academics that (a) racism hardly exists in contemporary Norway and that (b) the harassment of specific minority groups in Norway is not and cannot ever constitute racism?

In this article, I will, on the basis of an analysis of media and popular discourses on Islam and Muslims in Norway from 1987 and 2014 and by using the tools of what has become known as Critical Discourse Analysis or (CDA) (Blommaert and Bulcaen 2000, Wodak 1995, Fairclough 1992, Van Dijk 1992), argue that there is in fact little sustainable empirical evidence of a disappearance of racism and discrimination against minorities marked as 'other' through various processes of racialization (Barot and Bird 2001, Meer 2014) in present-day Norway. What we are seeing, rather, are the classical signs of liberal 'elite denials' of racism (van Dijk 1992), as articulated and 
refracted in academic literature, media practices, the legal sphere and so on. A central strategy in such 'elite denials' of racism in the Norwegian context in the modern era has been to restrict the concept of racism to a very narrow biological definition of racism, which explicitly requires the existence and expression of ideas about 'racial' hierarchies. In actual fact, academic literature has of course long made it abundantly clear that historical forms of racism from the very outset combined biological and cultural factors (Bethencourt 2013, Gilroy 2000), and that the high tide of biologically inflected racism which marked the era of so-called 'scientific racism' (Sussman 2014) is now long past us. In contemporary Norway, the mere referral to the term racism as indexing anything other than this now largely defunct historical racism based on biological indicators has for all practical purposes become taboo in the public sphere (Rogstad and Midtbøen 2010). A practical consequence of this development has also been that Norwegian courts tasked with applying the legal framework of Norwegian General Penal Code $\$ 135$ (a), first introduced in its present form in Norway in 1970 as a direct result of the Norwegian state's ratification of the UN's International Convention for the Elimination of All Forms of Racial Discrimination (ICERD, 1965) in the same year, have by and large limited the applicability of the law to instances of classical biological racism, even though the text of General Penal Code $\$ 135$ (a) makes it perfectly clear that it also applies to non-biological forms of racist and/or discriminatory speech (see Bangstad 2012 for this). The implication of this state of affairs in Norway is that it has to most intents and purposes become easier to be convicted for defaming individuals by publicly accusing them of racism under Norwegian General Penal Code $\$ 247$, than to get any individual convicted for racist and/or discriminatory speech under Norwegian General Penal Code $\$ 135$ (a).

There is also another aspect to liberal 'elite denials' of racism in the Norwegian context since the 1980s. And this is that liberal academics in Norway of the kind referred to above who have insisted on a narrow and restrictive biological definition of racism have not only failed to register and to reflect upon the substantial international academic scholarship on 'cultural racism' (Fanon 1967), 'new racism' (Baker 1981) and 'neo-racism' (Balibar 1991) since the 1980s internationally, they have also failed to note that far-right actors and activists in the Norwegian societal context ever since the 1980s have known perfectly well that in order to avoid accusations of racism and to increase one's appeal in, and to the political mainstream, one had better cease referring to 'race' and skin colour as indicators of immigrants and/or minority individuals alleged 'inferiority', and rather talk about 'culture' and/or 'ethnicity'. In this process, far-right actors and activists not only in Europe, but also in the context of wider Western Europe, have replaced 'race talk' with 'culture talk' (Mamdani 2002) and have shifted their primary targets from Jews to Muslims. Both these shift have in fact been documented in scholarly and other literature. In her ethnographic work on Norwegian neo-Nazis in and around the Norwegian capital of Oslo in the 1990s, the Norwegian sociologist Katrine Fangen found that though the discourses of these young, largely uneducated and socially marginalized white males from the Eastern suburbs of Oslo were shot through with racist and nationalistic assumptions, they generally avoided the terms 'race' and instead preferred the terms 'culture' and 'ethnicity' in talking about the immigrants and minorities they both despised and targeted (Fangen 2001: 155, 167, 168). It was from this very neo-Nazi milieu that the 
three murderers of fifteen-year old Benjamin Hermansen, a young Norwegian man of mixed Norwegian-African descent and a random victim of a brutal racist murder in Oslo would emerge in early 2001. Fangen actually notes that very few of her neo-Nazi informants had any interest whatsoever in books - either in Norwegian or English but these young neo-Nazis had actually understood perfectly well the strategic advantages of avoiding talk about 'race' and 'racial inferiority.' And this lesson has been learnt well by numerous Norwegian far-right activist organizations. More or less every far-right organization from The Popular Movement Against Immigration [Folkebevegelsen mot innvandring, FMI] via the Norwegian Defence League (NDL) to Stop the Islamisation of Norway [Stopp Islamiseringen av Norge] active in Norway in recent decades now routinely proclaim on their websites to be 'opposed to all forms of racism and xenophobia' and declare that they are merely 'opposed to the Islamisation of Norway', the 'Islamic colonization of Norway' or 'the introduction of shari'a in Norway.' Another cue is provided by the Norwegian far-right blogger Peder Are Nøstvold Jensen, known in international 'counter-jihadist' and Islamophobic circles under the alias 'Fjordman', who became a household name in Norway when it turned out that the mass murdering Norwegian terrorist Anders Behring Breivik was profoundly inspired by his internet writings and had reproduced some forty-three blog essays of his in his chilling 1518 pages long cut-and-paste tract 2083: A European Declaration of Independence. For in a key section of this tract, excerpted from 'Fjordman', Breivik declares that he - and by implication his fellow ideological travellers - "will not accept any accusations of racism." He goes on to advice his would-be-followers to avoid using the term 'race' as a means through which to avoid accusations of racism. What gives this rhetorical parlour game away in the case of both 'Fjordman' and Behring Breivik, however, is their mutual obsession with the question of 'racial purity' and the supposed perils of 'racial mixing' (Enebakk 2012: 66, Bangstad 2014: 93). For these were of course among the chief obsessions and concerns of every known racist state regime in modern history, from Jim Crow in the Southern states of the USA after the Civil War (1875-1960) via Nazi Germany (19331945) to apartheid South Africa (1948-1990). The historian Bjørn Westlie has for his part documented how former Norwegian volunteers to the Waffen SS during the German Nazi occupation of Norway (1940-45) by the late 1970s and early 1980s had simply shifted from regarding Jews as their primary enemies to regarding Muslims, who had gradually become more numerous as a result of labour migration from Pakistan, Morocco and Turkey to Norway from the late 1960s to 1975, subsequent family re-unification processes and an increased number of refugees in the $1980 \mathrm{~s}$, as the pre-eminent threat (Westlie 2008).

\section{'Raceless racism'}

We are in an era of what the sociologist David Theo Goldberg has described as 'raceless racism' (Goldberg 2006), and more than any other minority population in Norway, Muslims have proved eminently useful targets for the far-right in avoiding accusations of racism by enabling racist discourses centred upon Muslims' alleged or real 'culture', 'religion' and 'lifestyle'. A by now well-rehearsed argument even in 
liberal elite circles in Norway is that Muslims cannot under any circumstances be subject to racism, since Muslims do not constitute a 'race'. That argument of course pre-supposes that 'race' is ontologically 'real' rather than a mere artefact of socially constructed imaginaries - a view that finds very little support in serious scholarly literature on the topic (see Sussman 2014). But as the sociologists Tariq Modood and Nasar Meer have argued, it is by now more than clear that Muslims came to become subject to racism through processes of racialization, whereby individuals who 'look' Muslim in public are ascribed innate characteristics analogous to those of 'race' and these characteristics are cast as unchangeable and as a marker of alleged inferiority (Meer and Modood 2009). The question as to whether a person born to Muslim parents is a practising Muslim who identifies with the descriptor 'Muslim' as a category of self-definition or self-characterization or not is, as the religious scientist Mattias Gardell has noted, irrelevant in and to this process of racialization of Muslims (Gardell 2010). In the hard and crude forms of Islamophobia, by which here I mean to refer to "socially reproduced prejudices and aversions against Islam and Muslims, and actions and practices which attack, exclude and discriminate against people on account of these people either being, or being presumed to be Muslim, and to be associated with Islam" (Gardell 2010: 17, the author's translation) and "indiscriminate negative attitudes towards Islam and Muslims" (Bleich 2011: 1581), a 'Muslim is a Muslim is a Muslim', the signifier is over-determined and not for the Muslim herself to decide anything about what the term signifies. Islamophobia is in this - but not at all in all respects (Klug 2014) - analogous to classical anti-Semitism as analysed by the French philosopher Jean-Paul Sartre in his classical work Anti-Semite and Jew (Sartre 1995). This form of essentialization and its instrumentalization in processes of dehistorizing the emergence and maintenance of modern politico-religious identities is of course also - and paradoxically - found among Muslims themselves (Bowen 2012), making it even harder to do the hard analytical work required to avoid these conceptual entanglements. The caveat inferred by Bleich's emphasis on 'indiscriminate negative attitudes' for some attitudes, statements and/or practices to qualify as 'Islamophobic' is nevertheless important: fears relating to the ideas and practices of, for example, salafi-jihadists must in light of the terror threat from alQaida and other affiliate salafi-jihadi organizations and individuals that Western Europe - including Norway - has faced at least since 2001 are perfectly legitimate, as are fears and concerns relating to anti-Semitism, sectarian intolerance, homophobia and misogyny among certain groups of Muslims in Western Europe and Norway. It should also be clear that not all forms of Islamophobia qualify as racist. As the sociologist Ali Rattansi has pointed out, it is rather the hard and crude forms of Islamophobia which so qualify (Rattansi 2007: 108-109). ${ }^{1}$

\footnotetext{
1 Rattansi exemplifies what he refers to as 'hard' and 'crude' forms of Islamophobia - which he characterizes as racist - by reference to Serbian ultra-nationalist discourses on Islam and Muslims which preceded the attempted genocide on Bosnian Muslims during the Bosnia War from 1992 to 1996. For detailed analyses of these discourses, see Sells (2003) and Cigar (2003). In the Norwegian context, 'hard' and 'crude' forms of Islamophobia which are indisputably racist - and also in a biological racist sense can be exemplified by the writings of Peder Are Nøstvold Jensen - aka 'Fjordman' who has repeatedly
} 


\section{Neo-nationalism and neo-racism}

So what about the relationship between neo-nationalism and neo-racism then? Though there are certainly material determinants involved in the emergence of a new form of nationalism premised on opposition and hostility towards Islam and Muslims in Norway and the Nordic countries (Denmark, Sweden, Finland, Iceland and Norway), material factors are insufficient explanatory variables on and of their own. In a pun, the political scientist Cas Mudde refers to this as a case of it being "not the economy, stupid!" (Mudde 2007). Norway has of course weathered the financial crises affecting other Western European - and particularly Southern European - countries in dramatic ways exceptionally well. For Norway has remarkably low levels of youth and other unemployment, a stable economy, low levels of crime and social problems, and runs large state budget surpluses every year. Norway, in other words, still has all the features of the well-functioning welfare state with comparatively low levels of socioeconomic inequalities (Piketty 2014) which make it one of the best societies on earth to live in for the average citizen according to social scientists (Wilkinson and Pickett 2009). Where Mudde's pun becomes too simplistic, however, is in indicating that material determinants have little or nothing at all to do with the increased appeal of far-right political formations who have all traded on popular anti-immigration and antiMuslim sentiments in the Nordic countries in recent decades. For it is hardly coincidental in this context that the part of the electorate most likely to sympathize with, and to vote for the populist right-wing Progress Party in Norway are also the most likely to be lowly educated, be engaged in low-skilled and unstable service sector work, to be living on social welfare or unemployment benefits, and to be male and elderly of the electorate of any political party in Norway. In an era of a more or less permanent 'neo-liberal revolution' (Hall 2011), widening socio-economic inequalities and less access to stable, secure and permanent employment for the average citizen, these are then also as it happens among the Norwegians who rightly or wrongly feel that they have the most to fear from globalization and immigration. What populist right-wing political formations have succeeded in to a great extent not only in Norway but also in neighbouring Denmark, Sweden and Finland in recent decades and years is to render these material fears and anxieties, which affects a significant section of the electorate in profound ways, into what with reference to the political scientist Wendy Brown can be referred to as a 'culturalization of politics' (Brown 2006). In this 'culturalized politics', socio-economic problems and challenges are rendered as primarily cultural problems and challenges, so that for example immigrants and minorities facing exclusion on the labour and housing markets (a documented fact in Norway too) are understood to

incited violence against, and called for the ethnic cleansing of Muslims from Norway and Europe (Enebakk 2012: 73-74). It is perhaps not entirely co-incidental that Serbian ultra-nationalist discourses on Islam and Muslims have acted as a significant influence on authors in the far-right 'counter-jihadist' 'Eurabia'-genre in which 'Fjordman' writes: The doyenne of 'Eurabia'-authors is the Egyptian-born SwissIsraeli popular author Bat Ye'or (Gisèle Littman), who in the course of the 1990s established close contact with Serbian ultra-nationalist through her personal acquaintance with the one-time personal advisor to Radovan Karadžić and Biljana Plavsić, namely the US-based Serbian intellectual Sjirda (Serge) Trifković. It is a matter of record that 'Fjordman' has at least since 2006 had close contact with both Litman and Trifković. 
have brought this situation upon themselves by a 'refusal to integrate' and a 'refusal to live by societal norms' rather than for example as a result of labour market and housing discrimination on the part of Norwegians. In this 'culturalized politics', liberal norms and values, which the native population is seen as not only having, but being the very embodiment of, and the immigrant and/or minority populations as either lacking in or being incapable of aspiring to, assumes a central role. Taking its cue from the wildfire successes of the slain Dutch populist right-wing politician Pim Fortuyn's in assuming the mantle of a national guardian of liberal values that immigrants in general and Muslims in particular were cast as posing a threat to, as well as the changing societal norms on this in Norway and in Western Europe, populist right-wingers in Norway who had in the past cared precious little about LGBT and women's rights all of a sudden recast themselves as champions and bastions of liberal values and ideas. Hence we got what the Danish sociologist Sune Laegaard has insightfully referred to as a 'liberal nationalism' (Laegaard 2007). It is an analytical mistake to assume that the new nationalism's hostility to Islam and Muslims is limited to the far right (extreme or populist): part of its appeal lies precisely in its transcending left/right divides. A case in point is the fact that among the more vociferous proponents of the far-right, conspiratorial and profoundly Islamophobic 'Eurabia'genre in Norway (see Bangstad 2013, Larsson 2012, Pilbeam 2011), the central tenet of which is that the EU, European states and Muslim states in North Africa and the Middle East have since the onset of the EU's so-called 'Euro-Arab Dialogue' in the late 1970s secretly plotted to turn Europe into an Islamic dominion (state or caliphate) through inter alia mass immigration of Muslims, are people who have a background on the radical left in Norway in the 1970s. But it is certainly more widespread among the far-right sections of the electorate, opposition to immigration in general and Muslim immigration in particular having demonstrably been not only a central plank in the Norwegian populist right-wing Progress Party's political platform since the mid1980s, but also the single most attractive part of its political platform for its voters since then (see Hagelund 2003: 48 for this). That is however not to suggest that the PP is a proverbial 'one-issue party': the party turned from its origins as an anti-taxation and anti-bureaucratic party on the libertarian far-right in the 1970s to its full-scale embrace of the welfare state, women's and LGBT rights from the 1990s onwards. In analysing the 'neo-racism' and 'neo-nationalism' central to far-right discourses on Islam, Muslims and immigration in Norway since the 1980s, this article highlights the far-right 'realities' constructed in and through discourse, and how this discourse mobilizes what the cognitive linguist George M. Lakoff has referred to as 'hard-wired connotations' (Lakoff 2008) in which fears relating to the Muslim 'other' (whether male or female, but especially male) feature prominently. Though this far-right discourse is long-standing, it also forms part of quite a flexible discursive repertoire, which can be turned up and down according to political circumstances and electoral fortunes. As a case in point, it is noteworthy that the discourse on Islam and Muslims coming from the PP's central leadership in the immediate aftermath of the 22/7 2011 terror attacks in Norway was remarkably more civil in tone and tenor than what had been the case in the preceding months. This was partly a result of the early revelation that the extreme right-wing mass murdering terrorist Anders Behring Breivik had been a one time member of the Progress Party and its youth wing for no less than ten 
years in total until the onset of his withdrawal from society and spiralling radicalization from 2006 onwards and the revelation that his main motivation for these terror attacks was to instigate a civil war aimed at the ethnic cleansing of Norway and Europe of Muslims. Though the PP's central leadership has consistently refused to apologize for the PP's long-standing contribution to Islamophobia in Norway since 2001 by means of the mainstreaming of rhetorical tropes and ideas about Islam and Muslims which are clearly and discernibly of extreme right-wing provenance, the central party leadership's rhetoric on Islam and Muslims has since it entered government for the first time in the party's history after the September 2013 parliamentary elections, also been considerably more restrained, civil and courteous. All the while however, the party has lavished state funding on its long-standing supporters among far-right civil society activists in Norway, such as Hege Storhaug's Human Rights Service (HRS), and offered tacit approval for Progress Party MPs who continue to express and support Islamophobic ideas and sentiments in public in a game of rhetorical double play obviously geared towards keeping the 16 per cent of the party's voters who as late as in 2009 identified themselves as belonging to the 'extreme right' on the political spectrum within the party's political tent. ${ }^{2}$ With the party having together with its senior partner in government, the Conservative Party [Нøуre] proposed a state budget in September 2014 entailing enormous inheritance and income tax rebates for the corporate elite which makes up Norway's wealthiest 1 per cent and significant reductions in the welfare state support for poor people on disability grants lost much credibility and support among its key supporters in the electorate, it was hardly surprising that some of these erstwhile extreme-right wing supporters of the party had by then taken to describe the party's chairperson Ms Siv Jensen as a 'quisling' or 'traitor to the nation' on various social media, in a direct rhetorical mimicry of terms hitherto reserved for Norwegian social democrats of the Labour Party [Arbeiderpartiet].

\footnotetext{
${ }^{2}$ The data comes from a survey conducted by Axel West Pedersen at the Institute for Social Research (ISF) in Oslo, Norway in 2009 in which respondents were asked to identify which party they had voted for and to place themselves on a scale ranging from 1 (extreme left) to 10 (extreme right) on the political spectrum. It is however difficult to know what individual respondents may have meant by declaring themselves as being of 'extreme right-wing views', and whether this self-identification would in their own eyes also entail acceptance of the use of violent and non-democratic political means, as the descriptor 'extreme right-wing' is in fact commonly understood in Norway. But there is in light of the PP's modern history little doubt that the party has at times not only appealed to, but also actively consorted with extreme right-wing, Nazi and neo-Nazi sympathizers: In a secret meeting at Godlia Cinema in Oslo in 1995, the then vice-chairman of the party Øystein Hedstrøm canvassed the opinions of a number of leaders known to be involved in far-right racist and neo-Nazi organizations in Norway. When news of this was revealed by Norwegian tabloid newspapers at the time, the PP with great successfully accused the media of engaging in a 'witch hunt': the party actually gained a significant number of voters as a result of this scandal in the 1995 parliamentary elections.
} 


\section{The Progress Party discovers the electoral appeal of anti-Muslim rhetoric}

It was ahead of the 1987 parliamentary elections that the Progress Party under its legendary chairman Carl I. Hagen (1944 - ) first discovered the popular appeal of antiMuslim and anti-immigration rhetoric in Norway. At an election rally in September 1987 Carl Hagen read out a letter he alleged to have received from a Norwegian Muslim citizen by the name of Muhammad Mustafa. In the letter Mustafa was cited as having written the following:

Allah is Allah, and Muhammad is His Prophet! You are fighting in vain, Mr. Hagen! Islam, the only true faith, will conquer Norway too. One day, mosques will be as common in Norway as churches are today, and the children of my grandchildren will live to see this. I know, and all Muslims in Norway know, that one day, the Norwegian population will come to [the Islamic] faith, and that this country will be Muslim! We give birth to more children than you, and many a right-believing Muslim come to Norway each year, men in fertile age. One day, the heathen cross in the flag will be gone too!”3

The letter was a complete fabrication. The real Muhammad Mustafa, a pizza baker from Tøyen in Oslo, was paid out a substantial sum by the PP when he threatened Hagen with a defamation lawsuit. In the parliamentary elections of 1987, the PP obtained its hitherto best electoral result, gaining 12.1 per cent of the national vote. The background to the PP's success in channelling anti-immigrant sentiment lay in a significant rise in the number of people applying for asylum in Norway from 1986 to 1987, after Denmark had implemented new restrictions on asylum in 1986 (Jupskås 2009). A pattern had been set, and the PP's anti-immigration and antiMuslim rhetoric would hereafter become a regular staple of the party's political platform.

In May 2005, the PP's then spokesperson on immigration, the MP Per Sandberg, appeared in the tabloid newspaper VG stating that the PP parliamentary caucus had received 'information' from 'sources in the Pakistani milieu in Oslo' about a secretive extremist Muslim network in Oslo with '30 000 members of Pakistani origin' involved ( $V G$ 23.05.05). These 30000 members, Sandberg declared, had sworn an 'oath of loyalty' to the network. The network was said to be "fundamentalist, anti-democratic and potentially violent.” Members of the network, Sandberg alleged, had been looking for properties around Oslo with the intention of building mosques and facilities to be used for "training in violence." Sandberg duly informed the media that he was meeting the PST in order to report on the information he had obtained. Hege Storhaug's Human Right's Service (HRS) had also obtained the same 'information' and contacted the PST about it. The PST never made any statement on the case to the Norwegian media. The fabricated nature of the 'information' the PP and HRS had generously shared with the Norwegian public through the tabloid Verdens Gang $(\mathrm{VG})^{4}$ would be demonstrated through the fact that there were, as of

\footnotetext{
${ }^{3}$ A copy of the letter that Hagen alleged to have received is available here: http://www.dagbladet.no/2013/05/25/nyheter/politikk/frp/siv_jensen/carl_i_hagen/27336391/

${ }^{4}$ Verdens Gang, VG, is Norway's second largest print newspaper as measured in circulation, and the most widely read newspaper among PP voters.
} 
2004, only 26286 individuals of Pakistani origin in the whole of Norway - women and children included ( $\left.\varnothing_{\text {stby }} 2008: 18\right)$. The VG reporters who covered this news story appear not to have asked any critical questions whatsoever of Sandberg and Storhaug regarding their sources or figures.

\section{'Islamization by stealth'}

Ahead of the parliamentary election in September 2009, the PP leader Siv Jensen (1969 -) who succeeded Carl I. Hagen after he had resigned as party leader in 2006, in a speech to the Party Congress warned against what she referred to as the "islamization by stealth" ["snikislamisering"] of Norwegian society. "The reality is that we are at the point of allowing a stealth islamization of this society [i.e. Norway], and we have to put a stop to it", she asserted. "We cannot allow particular groups to decide the direction of societal development in Norway", rather, she averred, "We [i.e. in the PP] will not allow special demands [særkrar] from particular groups". Jensen listed as evidence of 'stealth islamization' demands by Muslim women to wear the hijab as part of police uniform; that Muslim inmates in Norwegian prisons be provided with halal food, and that some schools in Oslo were allegedly practising gender-segregated education. These demands had of course not been put forward in any 'stealthy' way, but very openly, and as a normal part of interest group politics in any liberal and secular democracy. The concept of 'islamization by stealth', which had been used by discussants on the web debate platform of the tabloid $V G$ as early as 2003 (Strømmen 2011: 191) is, regardless of its actual ethymological origins, a rhetorical concept which is strikingly similar to that found among counter-jihadists and 'Eurabia' fantasists who inspired Anders Breivik in the years leading up to 2011 (Strømmen op. cit.: 152). The prominent US Islamophobic author Robert Spencer in his book on 'stealth jihad', which seems to have popularized the term in 'counterjihadist' circles on the web, dates from 2008 (Spencer 2008). References to Spencer's work appear no less than 162 times in Breivik's 2083 (Lean 2012: 167), making Spencer the arguably most central ideological influence on Breivik (The Guardian 07.09.11) apart from the Norwegian blogger Peder Are 'Fjordman' Nøstvold Jensen. Spencer's concept of what stealth jihad entails is in many respects strikingly similar to that of Siv Jensen - namely a quiet subversion of 'our values' by Muslims using various non-violent and democratic means to further their purported agenda of 'Islamizing' Western societies. The PP's usage of this term provides a clear example of how political terms with a provenance in extreme right-wing and Islamophobic milieus online become part of mainstream political discourse (Døving 2012: 88). 


\section{The Rhetoric Intensifies: 2010 and 2011}

2010 and 2011 saw an intensification of Islamophobic rhetoric emanating from PP MPs. In May 2011, Christian Tybring-Gjedde, an MP for the party from Oslo and Chairman of the Oslo PP, addressed the party's national congress. In his October 2010 speech to the 'Friends of Document.no', a speech later made available on the internet by Document.no, Tybring-Gjedde alleged that '90 percent of all immigration to Europe after 1990 had been from Muslim countries', and that there would be 'an estimated 52 million Muslims in Europe by 2025' (see VG.no 01.09.11). Both claims are grossly inaccurate, and are based on fabricated demographic scenarios found in 'Eurabia'- literature (see Larsson 2012, and Pilbaum 2011).

In an opinion piece published by Aftenposten in August 2010 Tybring-Gjedde and his PP party colleague Kent Andersen had accused the governing Norwegian Labour Party of 'wanting to tear the country apart' by allowing 'thousands of immigrants' with their 'un-culture' [ukultur] into the country every year: 'What is wrong with Norwegian culture, since the Labour Party wants to replace it with multiculture?', thundered Tybring-Gjedde. Indeed, Tybring-Gjedde and Andersen stated that multiculturalism 'represents structured rootlessness, and will tear our country apart' (Aftenposten 25.08.10). In January 2011 Andersen wrote on his personal blog that there were 'striking similarities between the three great ideologies of humankind: Nazism, Communism and Islam'. One notes here how Islam is deliberately construed as a political ideology rather than a religion. This construction is central to much Islamophobic and Eurabia literature from recent years, and can also be found in Breivik's 2083. The analogy between Islam and Nazism and/or Communism, a rhetorical trope used by Islamophobic right-wing European politicians from Geert Wilders of the Dutch PVV to Marine Le Pen of the French FN, does of course also suggest that Islam will have to be fought by non-Muslim Europeans in manners similar to those used to fight Nazism and Communism. And this 'fighting' in Andersen's conceptualization, would seem not to exclude violence.

Andersen also raised the question, on his blog, as to whether 'moderate Muslims' actually exist - 'as if there was something like"'moderate Nazis"' (Dagsavisen 01.02.11). This rhetorical trope also stands in debt to Islamophobic and 'Eurabia' literature, in which a central tenet is that, to the extent Muslims publicly abhor violence, terrorism, and so forth, they are being disingenuous about 'real Islam', that is, the Islam of violence and terrorism, and in fact practice dissimulation, or taqiyya. But in the work of the Eurabia author Bat Ye'or, and in the understandings of her followers, among them Anders Behring Breivik, taqiyya is rather understood as 'lies' or 'deceptions' through which Muslims everywhere in the world 'conceal' their 'real' intentions of Islamic dominance over non-Muslim peoples. Accordingly, Muslims, whatever their orientation or beliefs, are never to be trusted. All Muslims and Islamists (whether radical or moderate) are part of the same plot. The term taqiyya had in fact been known and used in PP circles for quite some time before 2011. When the then leader, Carl Hagen, in August 2004 protested against the Norwegian Conservative Party-dominated government's permitting the Pakistani politician MP Qazi Hussein Ahmed of the Islamist Jamaat e-Islami to visit Norway and Oslo for Pakistani national day celebrations, he alleged to the liberal tabloid VG that 'according 
to the Qur'an, it is perfectly acceptable to lie to and deceive the infidels, including us Christians' ( $V G$ 10.08.04). In two following letters to the editor at VG, Hagen, referencing a 2002 book in Danish by Lars Hedegaard on the alleged impending Islamic colonization of the West referred the 'so-called tactic of taqiyya', which 'permits fanatical Islamists to walk around in Western attire, drink alcohol, behave like well-integrated immigrants, in short, to conceal their real aims to their surroundings and Western police' ( VG 23.08.04).

The significance of this concept for Islamophobes is that it raises the prospect that there are no people of Muslim background that are to be trusted under any circumstances, since the practice of taqiyya, to their minds, gives license to dissimulating even the absence of Islamic faith. There are, consequently, no such things as 'good' and bad' Muslims (Mamdani 2004). The division between those two categories is by and large a product of fiction. Andersen was unapologetic when contacted about these postings by a Norwegian newspaper in February 2011. TybringGjedde refused to take any exceptions to Andersen's statements about Islam; PP Party Chairman Siv Jensen refused to comment and the PP's then Spokesperson on Immigration and Integration, MP Per Willy Amundsen, characterized Andersen's statements as 'interesting' and 'completely unproblematic' (Dagsavisen 01.02.11). Tybring-Gjedde's address to the PP party congress in May 2011 would take this one step further. Here, with reference to Groruddalen in Oslo East, he would argue that immigrant boys were 'hissigere' ['angrier] than Norwegian boys. In Norwegian, hissig is a term which connotes anger and resentment and a lack of self-control and selfrestraint which potentially leads to violence (VG.no 13.05.11). Groruddalen, a large area in Oslo East built on the initiative of post World War II social democratic governments as areas meant to offer affordable housing units for Oslo's working-class population, today has some of the residential areas in Oslo and in Norway with the highest proportion of residents of non-Western background. It is by no means dominated by Muslims, as popular legend and Progress Party rhetoric have long suggested. It was Muslim residents of Groruddalen in particular that Tybring-Gjedde had in mind. That much was also evident from the assertion later in his speech to the effect that 'Islam cannot stand values of freedom, and the power of Islam [in Norway] increases day by day. Therefore, immigration from Muslim countries must be substantially reduced.' Returning to his charge of the social-democratic and governing Labour Party having turned Norway into a 'multicultural Disneyland', Tybring-Gjedde concluded by listing a series of political demands from the Labour Party as well as the Conservative Party [Høyre]. Among these were the demand that new immigrants in Norway were to be welcomed with 'unconditional love [ubetinget kjærlighet] to Norway and our [my emphasis] Christian cultural heritage.' 


\section{The Progress Party in government, 2013-14}

The PP came to power as a junior partner in government for the first time in its forty year history after the parliamentary elections of September 2013. That led to cabinet ministers and the central party leadership - which is drawn from the party's educated technocratic elite - adopting a much more civil discourse on Islam, Muslims and immigration than what had been the case in opposition. Yet this faction of the party continued to display a high level of tolerance for MPs who engaged in Islamophobic rhetoric. For cases in point, one could point to the PP's vice-chairman Per Sandberg MP, who, as we have seen previously, has a long-standing record of problems in sorting empirical facts from personal fantasies, in his autobiography from 2013 (Sandberg 2013) fabricated claims to the effect that a small local municipality on the West Coast of Norway had been forced to build an entire new school to accommodate the biological offspring of one Norwegian-Somalian man who had allegedly tricked Norwegian immigration authorities into allowing him to settle with his polygynous wives in Norway in breach of Norwegian law (which only permits a man to have one wife at a time), and producing no fewer than twenty-two children. When a local newspaper reporter documented that the story was a complete fabrication (Hattestad 2013a), Sandberg responded with a shrug of the shoulders and alleged that "my readers would understand - for it could have happened" (Hattestad 2013b). There was no reaction from the PP's central leadership. A further case in point is provided by the case of the vice chairman of the party's parliamentary caucus and spokesperson on Justice MP Ulf Leirstein (1973 -), whose September 2014 endorsement of doctored You Tube-videos suggesting that his fellow MP Hadia Tajik (1983 -) on the Justice Committee ${ }^{5}$ was practicing taqiyya and in reality supported ISIS' beheadings and other human rights violations perpetrated by ISIS on Facebook ${ }^{6}$ went completely unsanctioned and were even tacitly supported in the name of a purported defence of 'freedom of expression' by the PP's central leadership.

\section{Conclusion}

In this article, I have argued that the referral to the term racism has for all practical purposes become taboo in the public sphere. The enabling circumstance for this state of affairs has been the rise of populist right-wing formations in Norwegian politics on a discernibly anti-immigration and anti-Muslim platform, the shifting rhetorical registers of racism from biological to cultural and/or religious markers of hierarchized difference, liberal 'elite denials' of racism, and the comparatively weak traditions of social science scholarship on racism in Norway. This article has analysed far-right discourses on Islam and Muslims and immigration in Norway in the period between

\footnotetext{
${ }^{5}$ Tajik is a former Minister of Culture for the Labour Party 2012-2013, the first ever cabinet minister of Muslim background in Norway and Chair of the Parliamentary Committee on Justice. She is the second child of a Pakistani-Afghan migrant labour couple who arrived in Norway in the 1970 s, and is known for her vocal opposition to salafi-jihadism.

${ }^{6}$ See http://www.dagbladet.no/2014/08/23/nyheter/politikk/innenriks/samfunn/ulf_leirstein/34934708/ for this.
} 
1987 and 2014. I have demonstrated that much of this discourse, while not being static and unchangeable, mobilizes popular fears and sentiments by casting Muslims as perennial outsiders in neo-nationalist imaginaries. Though not necessarily and inevitably neo-racist, this Islamophobic discourse has been and is certainly at times based on the hierarchical inferiorization of Muslims by means of the overdetermination of the signifier 'Muslim' and 'Islam' and the essentialization of their inter-linkages. Liberal 'elite denials' of racism which proceeds from a narrow and restrictive definition of racism as being exclusively biological cannot and will not countenance recognizing 'hard' and 'crude' forms of Islamophobia as racist, and to acknowledge the existence of racism directed at Muslims in Norway. Whether the vicious cycles this has set in motion in recent Norwegian history can be broken in the years to come remains to be seen.

\section{References}

Alstadsæter, R. (2004) Hagen agrep islam (Hagen Attacked Islam), Nrk.no 13 July.

Back, L. and J. Solomos (2000) (eds.) Theories of Race and Racism: A Reader. New York: Routledge.

Baker, M. (1981) The New Racism: Conservatism and the Ideology of the Tribes. London: Junction Books.

Balibar, E. (1991) Is There A Neo-Racism? In Balibar, E. and Wallerstein, I. (eds.) Race, Nation, Class: Ambiguous Identities. London and New York: Verso. 17-28.

Bangstad, S. (2012) Failing to Protect Minorities Against Racist and/or Discriminatory Speech? The Case of Norway and $\$ 135$ (a) of the Norwegian General Penal Code, Nordic Journal of Human Rights, 30 (4): 483-514.

Bangstad, S. (2013) Eurabia Comes to Norway, Islam and Christian-Muslim Relations, 24 (3): 369-391.

Bangstad, S. (2014) Anders Breivik and The Rise of Islamophobia. New York: Zed Books.

Barot, R. and J. Bird (2001) Racialization: The Genealogy and Critique of a Concept, Ethnic and Racial Studies, 24 (4): 601-618.

Bethencourt, F. (2013) Racisms: From the Crusades to the Twentieth Century. Princeton, NJ: Princeton University Press.

Bleich, E. (2011) What is Islamophobia, and How Much Is There? Theorizing and Measuring an Emerging Comparative Concept, American Behavioral Scientist, 55 (12): 1581-1600.

Blommaert, J. and C. Bulcaen (2000) Critical Discourse Analysis, Annual Review of Anthropology, 29: 447-466.

Bowen, J. R. (2012) A New Anthropology of Islam. Cambridge, UK: Cambridge University Press. 
Brown, W. (2006) Regulating Aversion: Tolerance in the Age of Identity and Empire. Princeton, NJ: Princeton University Press.

Bulmer, M. and J. Solomos (1999) (eds.) Racism: A Reader. Oxford: Oxford University Press.

Cigar, N. (2003) The Nationalist Serbian Intellectuals and Islam: Defining and Eliminating a Muslim Community. In Qureshi, E. and M. A. Sells (eds.) The New Crusades: Constructing The Muslim Enemy. New York: Columbia University Press.

Døving, C. A. (2012) Norge snikislamiseres (Norway Undergoing Stealth Islamization). In Indregaard, S. (ed.) Motgift: Akademisk respons på den nye høyreekstremismen (Counterpoison: Academic Responses on the New Right-wing Extremism), Oslo: Manifest/Flamme Forlag. 87-97.

Enebakk, V. (2012) Radikaliseringen av Fjordman (The Radicalisation of Fjordman). In Sørensen, Ø., B. Hagtvet and B. A. Steine (eds.) Høyreekstreme ideer og bevegelser i Europa (Extreme Right-Wing Ideas and Movements in Europe), Oslo: Dreyer. 45-101.

Fairclough, N. (1992) Discourse and Social Change. Cambridge: Polity Press.

Fangen, K. (2001) En bok om nynazister (A Book About Neo-Nazis). Oslo: Universitetsforlaget.

Fanon, F. (1967) Black Skins, White Masks. New York: Grove Press.

Fredrickson, G. M. (2002) Racism: A Short History. Princeton, NJ: Princeton University Press.

Gardell, M. (2010) Islamofobi (Islamophobia). Stockholm: Leopard Förlag.

Gilroy, P. (2000) Against Race: Imagining Political Culture Beyond The Color Line. Cambridge, MA: The Belknap Press of Harvard University Press.

Gjerdåker, S. (2007) Slutt å kalle fordommar for rasisme (Stop Referring to Prejudices as Racism). Dag og Tid 21 September.

Goldberg, D. T. (2006) Racial Europeanization, Ethnic and Racial Studies, 29 (2): 331-364.

Hagelund, A. (2003) A Matter of Decency? The Progress Party in Norwegian Immigration Politics. Journal of Ethnic and Migration Studies, 29 (1): 47-65.

Hall, S. (2011) The Neo-liberal Revolution. Cultural Studies, 25 (6): 705-728.

Hattestein, H. (2013a) Per Sandbergs bok: Fri diktning om Svelgen (Per Sandberg's Book: Free Association about Svelgen). Firdaposten.no 12-12-2013.

Hattestein, H. (2013b) Eg trur at lesarane forstår poenget mitt (I Think My Readers Understand My Point). Firdaposten.no 12-12-2013.

Jupskås, A. R. (2009) Høyrepopulisme på norsk. Historien om Anders Langes Parti og Fremskrittspartiet (Right-wing Populism in Norwegian. The Story of Anders 
Lange's Party and the Progress Party). In Simonsen, T. E., A. G. Kjøstvedt and K. Randin (eds.) Høyrepopulisme i Europa (Right-wing Populism in Europe). Oslo: Unipub. 27-79.

Klug, B. (2014) The Limits of Analogy: Comparing Islamophobia and Antisemitism. Patterns of Prejudice, 48 (5): 442-459.

Laegaard, S. (2007) Liberal Nationalism and the Nationalisation of Liberal Values. Nations and Nationalism, 13 (1): 37-55.

Lakoff, G. M. (2008) The Political Mind: Why You Can't Understand 21 Century American Politics with an $18^{\text {h }}$ Century Brain. New York: Viking Books.

Larsson, G. (2012) The Fear of Small Numbers: Eurabia Literature and Censuses on National Belonging, Journal of Muslims in Europe, 1: 142-165.

Mamdani, M. (2002) Good Muslim, Bad Muslim: A Political Perspective on Culture and Terrorism. American Anthropologist, 104 (3): 766-775.

Meer, N. (2014) (ed.) Racialization and Religion. Race, Culture and Difference in the Study of Antisemititism and Islamophobia. New York: Routledge.

Meer, N. and T. Modood (2009) Refutations of Racism in the 'Muslim question', Patterns of Prejudice, 43 (4): 335-354.

Mudde, C. (2007) Populist Radical-Right Parties in Europe. Cambridge, UK: Cambridge University Press.

Østby, L. (2008) Levekårsundersøkelse blant innvandrere - hvordan og hvorfor (Quality of Life Study Among Immigrants - the How and Why). In Blom, S. and K. Henriksen (eds.) Levekair blant innvandrere i Norge 2005/2006 (Quality of Life among Immigrants to Norway 2005/2006), Oslo: Statistisk Sentralbyrå/Statistics Norway. 15-26.

Piketty, T. (2014) Capital in the Twenty-First Century. (Translated by A. Goldhammer.) Cambridge, MA: Harvard University Press.

Pilbeam, B. (2011) Eurabian Nightmares: American Conservative Discourses and the Islamisation of Europe. Journal of Transatlantic Studies, 9 (2): 151-171.

Rattansi, A. (2007) Racism: A Very Short Introduction. Oxford: Oxford University Press.

Rogstad, J. and A. H. Midtbøen (2010) Den utdannede, den drepte og den glemte: Mot en ny forståelse av rasisme og diskriminering (The Educated, the Murdered and the Forgotten One: Towards a New Understanding of Racism and Discrimination). Sosiologisk Tidsskrift, 18 (1): 31-52.

Sandberg, P. (2013) Mot min vilje. Oppklaring av et politisk liv (Against My Will: Explanations for a Political Life). Oslo: Juritzen.

Sartre, J-P. [1948] (1995). Anti-Semite and Jew: An Exploration of the Etiology of Hate. (Translated by G. J. Becker). New York: Shocken Books. 
Sells, M. A. (2003) Christ Killer, Kremlin, Contagion. In Qureshi, E. and M. A. Sells (eds.) The New Crusades: Constructing The Muslim Enemy. New York: Columbia University Press.

Simenstad, L. M. (2011) Antirasistene er de eneste som opprettholder rasebegrepet (Anti-Racists Are the Only Ones Who Maintain the Concept of Race), Klassekampen 25 August.

Spencer, R. (2008) Stealth Jihad: How Radical Islam is Subverting America Without Guns or Bombs. Washington, D. C.: Regency Publishing.

Strømmen, Ø. (2011) Det mørke nettet. Om høyreekstremisme, kontrajihadisme og terror i Europa (The Dark Net. On Right-wing Extremism, Contra-jihadism and Terror in Europe). Oslo: Cappelen Damm.

Sussman, R. W. (2014) The Myth of Race: The Troubling Persistence of an Unscientific Idea. Cambridge, MA: Harvard University Press.

Tjønn, H., A. K. Christiansen and T. Haugfos (2004) Jubel for Hagens utfall mot Muhammed ('Cheers for Hagen's Attack on Islam'), Aftenposten 14 July.

Tybring-Gjedde, C. (2014) Mens orkesteret fortsetter å spille (Whilst the Band Plays On). Oslo: Cappelen Damm.

Van Dijk, T. A. (1992) 'Discourse and the Denial of Racism', Discourse and Society, 3 (1): $87-118$.

Westlie, B. (2008) Min fars krig (My Father's War). Oslo: Aschehoug.

Wilkinson, R. G. and K. Pickett (2009) The Spirit Level: Why More Equal Societies Almost Always Do Better. London: Allen Lane.

Wodak, R. (1995) Critical Linguistics and Critical Discourse Analysis. In Verscheuren, J., J. O. Östman, J. Blommaert and C. Bulcaen (eds.) Handbook of Pragmatics, Amsterdam: John Benjamins. 204-210. 